\title{
FABA BEAN GROWTH AND YIELD AS AFFECTED BY APPLICATION METHODS OF IRON OR MANGANESE Abdo, Fatma, A. ${ }^{1}$ and Sabah M. Attia ${ }^{2}$
}

1. Crop Physiology Res., Dep., Field Crops Res. Institute, Agric. Res. Center, Giza, Egypt.

2. Food legumes Res. Dep., Field Crops Res. Institute, Agric. Res. Center, Giza, Egypt.

\begin{abstract}
A field experiment was carried out at Giza experimental Station, Agricultural Research Center (ARC), during 2004/2005 and 2005/2006 seasons. The main objective was to study the effect of either iron (Fe) or manganese (Mn) application methods, viz. seed coating at rates of $0.2 \mathrm{~g} \mathrm{Fe}$ or $0.3 \mathrm{~g} \mathrm{Mn} / 1 \mathrm{~kg}$ seed, foliar application at 200 ppm Fe or 300 ppm Mn 45 days after sowing (DAS) and the combination of both methods on growth, yield and seed quality of Giza 40 and Nubaria 1 faba bean cultivars. The split plot design with three replications was used. Results showed that Giza 40 produced significantly taller plants at 64, 85, 106 and 127 DAS. It was also superior in plant shoot dry weight at 64 and 85 DAS. The same trend was true at harvest regarding pod number / plant in both seasons. However, Nubaria 1 surpassed Giza 40 in plant shoot dry weight at 106 and 127 DAS. In addition, Nubaria 1 was superior to Giza 40 in leaf area (LA) / plant at all growth ages, 100 -seed weight, seed weight / plant, seed and straw yields / feddan as well as seed crude protein, $\mathrm{Fe}$ and $\mathrm{Mn}$ contents. All treatments induced significant increases over the control in all investigated yield traits in both seasons. Foliar application of Fe was the most effective treatment in this respect followed by foliar application of $\mathrm{Mn}$. The average increases due to foliar application of Fe were $20.4,42.8,14.2$ and $23.2 \%$ for number of pods / plant, seed weight / plant, 100-seed weight and seed yield / feddan, respectively compared with control. Results also indicated that foliar application of either Fe or Mn could have improved yield and seed quality traits. The improvement in seed protein, total carbohydrate, Fe and $\mathrm{Mn}$ contents due to foliar application over coating or coating + spraying methods were 4.8 and $3.9 \%$ for crude protein, 6.1 and $5.5 \%$ for total carbohydrates, 11.1 and $7.5 \%$ for Fe and 10.4 and $7.2 \%$ for $\mathrm{Mn}$, respectively.
\end{abstract}

Keywords: Faba bean, Seed coating, Foliar application, Fe, Mn, Growth, Photosynthetic pigments, Yield, Seed quality.

\section{INTRODUCTION}

Faba bean (Vicia faba L.) is the most important food legume in Egypt. The local production is often below the country requirements. Thus, it becomes urgent to seek several avenues to boost production to meet the increasing demand for food.

Under field conditions, deficiency in Fe and $\mathrm{Mn}$ is usually confined to plants grown in highly leached tropical soils or high $\mathrm{Ph}$ soils with a large organic matter content. So, it can be corrected through foliar or soil applications of $\mathrm{Fe}$ and Mn (Azer et al., 1992). The efficiency of micronutrient fertilization depends mainly on the method of application (soil application, foliar application or seed coating) and micronutrient fertilizer source (salts or acids or chelates). 
El-Mansi et al. (1991) on faba bean, reported that plant height, shoot dry weight (at 50, 70 and 90 days after sowing), photosynthetic pigments in leaves and some yield components were significantly increased when plants were sprayed with $1000 \mathrm{ppm} \mathrm{Fe}$. At the mean time, it was found that foliar application with $\mathrm{Mn}$ at 1000 or $2000 \mathrm{ppm}$ had in general a determined effect on most of the studied characters.

Hegazy et al. (1992) and Osman et al. (1992) on faba bean found that seed coating method with either $0.15 \mathrm{~g} \mathrm{Mn}$ EDTA or $0.3 \mathrm{~g} \mathrm{Fe} \mathrm{EDTA} \mathrm{/} \mathrm{Kg}$ seed gave better growth traits and yield components. Azer et al. (1992) stated that seed and protein yields of lentil and faba bean were significantly increased as $\mathrm{Mn}$ was applied at the rate of $0.24 \mathrm{~g} / \mathrm{kg}$ seed, while the highest rate of 0.48 $\mathrm{g} / \mathrm{kg}$ seed showed lower response. Abido et al. (1995) applied Fe or Mn foliarly in chelate form at the rate of $0.3 \mathrm{~g} / \mathrm{L}$. The results showed that all treatments caused increases in seed and straw yields. They found that the effect of Fe surpassed Mn.

Abdel-Aziz and Anton (1999) on faba bean, mentioned that seed coating at a rate of $0.3 \mathrm{~g} / \mathrm{kg}$ seed for $\mathrm{Fe}$ and $\mathrm{Mn}$ significantly increased plant height, leaf area / plant, number of pods / plant, seed and straw yields / plant, straw and seed yields / feddan. Such treatment increased seed protein content. However, total carbohydrate content was decreased.

The effect of seed coating with $\mathrm{Mn}$ at $0.15 \mathrm{~g}$ and/or $0.3 \mathrm{~g}$ Fe in form of EDTA / Kg seed of faba bean was investigated by Nassar et al. (2002 a and b). This results indicated that micronutrients treatments increased plant height, dry matter of different plant organs, photosynthetic pigments, micronutrient contents in leaves and seeds as well as seed yield and its components. Moreover, they found that seed yield was significantly correlated with seed $\mathrm{Mn}$ and Fe contents.

Nenova (2006) applied Fe at rates of $0.1,2.0,10.0$ or $40.0 \mathrm{mg} / \mathrm{L}$ on pea plants grown hydroponically and stated that $\mathrm{Fe}$ at the rate of $2.0 \mathrm{mg} / \mathrm{L}$ gave the most favourable effect on plant growth and pigment content. It was found that such treatment increased shoot length, dry biomass, total chlorophyll and carotenoides contents.

The present investigation aimed to determine the best method of applying micronutrients; i.e., seed coating, foliar spraying and their combination on two cultivars of faba bean. Plant growth, yield and yield components as well as seed chemical composition (seed quality) were investigated.

\section{MATERIALS AND METHODS}

The present investigation was carried out at Giza Experimental Station, ARC, during 2004 / 2005 and 2005 / 2006 seasons to study the effect of iron $(\mathrm{Fe})$ and manganese $(\mathrm{Mn})$ application methods (seed coating, foliar spray and coating combined with foliar spray) on growth and yield of Giza 40 (selection from Rebaya 40, early maturing) and Nubaria 1 (selection from Giza Blanca, late maturing) faba bean cultivars. 
Physical and chemical soil analyses for the experimental sites were carried out according to Chapman and Pratt (1961) and Jackson (1967), and results are presented in Table (1).

Table 1: Physical and chemical analyses of the experimental soil.

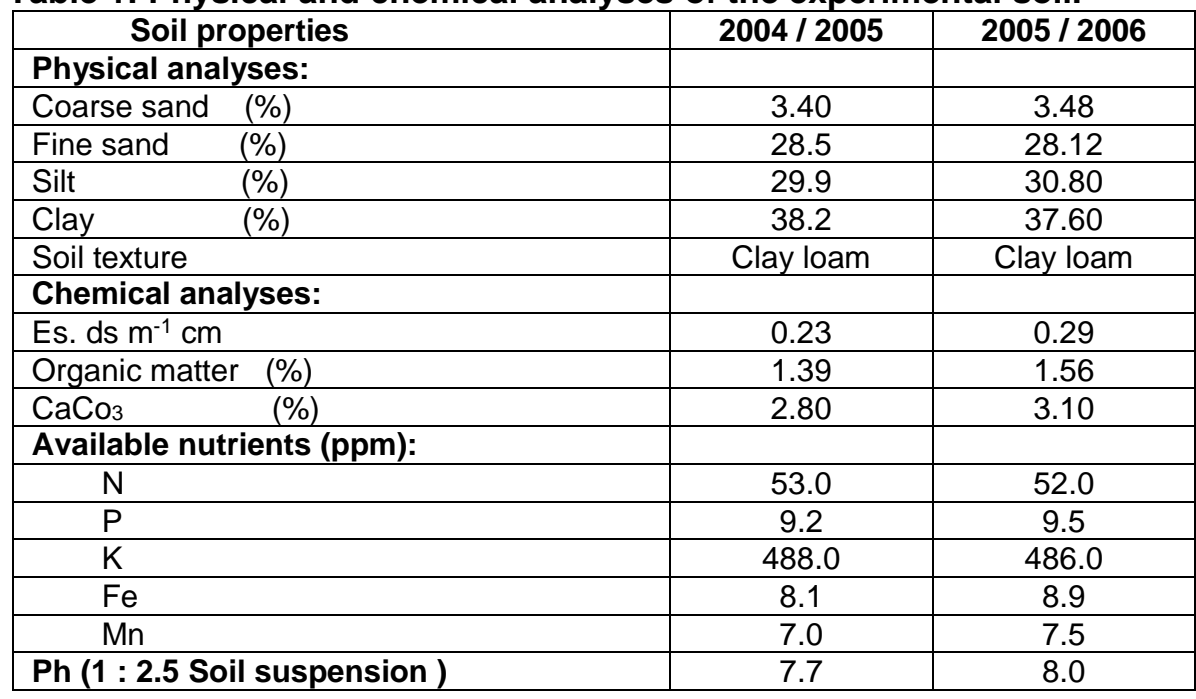

A split plot design with three replication was used. Main plots were devoted to cultivars, whereas sub-plots comprised micronutrients treatments including without treated, seed coating, foliar spray and coating combined with foliar spray. Each sub-plot was $10.8 \mathrm{~m}^{2}$ (six ridges, three meters long and $60 \mathrm{~cm}$ apart).

Coating treatments were carried out before planting. Seeds were coated with $\mathrm{Fe}$ and $\mathrm{Mn}$ at rates of 0.2 and $0.3 \mathrm{~g} / \mathrm{kg}$ seed, respectively. Seeds were first damped with a solution of a sticker substance (Triton B) and mixed with the chelated substance of tested micronutrients. The coated seeds were air dried just before sowing. For foliar application method, plants were sprayed with either 200 ppm Fe or 300 ppm Mn 45 days after sowing. The combined treatment for each micronutrient was applied at same rates mentioned. Fe and $\mathrm{Mn}$ were applied in the form of ethylenediamine tetraacetic acid (EDTA) compound.

Seed was sown in hills $20 \mathrm{~cm}$ apart on both sides of ridges. Sowing took place on 10 November in both seasons. Three weeks after planting, seedlings were thinned at one plant per hill. Other cultural practices were applied as recommended.

\section{Data recorded:}

\section{A. Growth traits:}

A sample of five plants was randomly taken from the second ridge of each sub-plot at 64, 85, 106 and 127 days after sowing (DAS) to measure the following traits:

1. Plant height $(\mathrm{cm})$. 
2. Shoot dry weight per plant (g), for dry weight determination, plant shoot was dried at $70^{\circ} \mathrm{C}$ in an electric oven to a constant weight.

3. Leaf area (LA) per plant $\left(\mathrm{dcm}^{2}\right)$ was determined according to the following formulae:

$\mathrm{LA}=($ Disc area $\times$ No. of disks $) \times$ dry weight of leaves per plant $/$ dry weight of leaves disk

B. Chemical analysis in faba bean leaves:

Chemical analysis was done only in 2005 / 2006 season:

Total chlorophyll (chl a $+\mathrm{chl} b)$ and carotenoides ( $\mathrm{mg} / \mathrm{g}$ fresh weight),

Fe and $\mathrm{Mn}(\mathrm{ppm})$ were determined in the third uppermost leaf at 80 DAS.

Photosynthetic pigments were determined after acetone $85 \%$ extraction according to Arnon (1949) and calculated according to A.O.A.C. (1990).

Whereas, Fe and Mn were determined by atomic spectrophotometer IL-157 (Cottenie et al., 1982).

C. Yield and yield components:

In both seasons, harvesting was done during the first and third weeks of April for Giza 40 and Nubaria 1, respectively. Five plants were randomly taken from each sub-plot and the following traits were determined:

- Pod number per plant.

- Seed weight per plant (g).

In addition, seed and straw yields per feddan as well as 100 seed weight were determined from the three central ridges in each sub-plot.

D. Some chemical constituents of seeds (seed quality):

Samples of mature dried seeds were finely ground and chemical analysis were carried out in three replicates on samples taken from the second season of 2005 / 2006. The following determinations were conducted:

1. Total carbohydrates were determined as glucose (\%) according to Dubois et al. (1956).

2. Crude protein (\%) was determined by micro. Kieldahl method,.total nitrogen was multiplied by 6.25 according to A.O.A.C. (1990).

3. Fe and $\mathrm{Mn}(\mathrm{ppm})$ were determined by atomic spectrophotometer (Cottenie et al., 1982).

Statistical analysis:

Data were statistically analyzed according to Steel and Torrie (1980). Homogeneity test for the data of the two seasons was done. Therefore, the discussion was held on the mean of the two seasons except chemical analysis (one season only).

\section{RESULTS AND DISCUSSION}

A. Growth traits:

Results in Table (2) indicate that faba bean cv. Giza 40 surpassed cv. Nubaria 1 in plant height at all growth ages in each season as well as in combined analysis of both seasons. With respect to the shoot dry weight per plant (Table 3), Giza 40 was superior to Nubaria 1 at the first two ages; i.e. 64 and 85 days after sowing (DAS). However, Nubaria 1 surpassed Giza 40 in shoot dry weight at the last two ages of plant growth (106 and 127 DAS). 
Regarding total leaf area / plant (Table 4), Nubaria 1 was superior to Giza 40 cultivar at all studied ages of plant growth. In general the differences between the two cultivars were significant in combined analysis of both seasons.

As for the effect of nutrient application treatments, it was evident that all treatments surpassed the control. This held true for all investigated traits at all growth ages. In this respect, it was found that foliar application of $\mathrm{Fe}$ gave higher values for all investigated morphological traits at all growth ages in each season and in combined analysis of both seasons. Such treatment was the best followed by foliar application of $\mathrm{Mn}$ and seed coating with $\mathrm{Fe}$.

Foliar spray was the most effective method of application for improving growth traits, viz. plant height, plant shoot dry weight and total plant leaf area at all growth ages followed by seed coating and the combined treatment, i.e. seed coating + foliar spray. Such improvement in growth traits of the investigated faba bean cultivars due to micronutrient foliar spray was found to be significant over the other methods of application.

The interaction between cultivars and micronutrient treatments was found to be significant at all growth ages, except at 64 DAS, for all growth traits. In this respect, it was found that foliar application of Giza 40 with $\mathrm{Fe}$ gave higher values for plant height followed by foliar application with $\mathrm{Mn}$. With respect to shoot dry weight it is clear that foliar application with $\mathrm{Fe}$ gave higher value in the second age of plant growth (85 DAS) for Giza 40 cultivar, whereas the higher value in the third and fourth ages of plant growth (106 and 127 DAS) was found in Nubaria 1. At the same time, Nubaria 1 gave higher values of total leaf area in the last three ages of plant growth when plants were sprayed with Fe. Likewise, total leaf area / plant of Giza 40 at 106 DAS showed higher values when plants were sprayed with $\mathrm{Mn}$ and the difference between spraying $\mathrm{Mn}$ and spraying Fe proved significant in this concern.

Interaction between cultivars and application method was not significant for all investigated traits at all growth ages (except plant shoot dry weight and total plant leaf area at 106 DAS), with respect to combined analysis of both seasons (Table 2, 3 and 4).

These results are generally in agreement with those obtained by ElMansi et al. (1991) on faba bean and Nenova (2006) on pea who pointed out that foliar spray with $\mathrm{Fe}$ had favourable effects on plant height and dry weight of different plant organs. On the other hand, Azer et al. (1992) on lentil and faba bean as well as Hegazy et al. (1992), Osman et al. (1992) and AbdelAziz and Anton (1999) on faba bean reported that seed coating method gave better growth relative to foliar application method.

The response of faba bean plants to $\mathrm{Fe}$ and $\mathrm{Mn}$ may be due to the important role of these elements in enzyme activation and hormone regulation, in metabolism of carbohydrates, protein and auxins and also in multiple processes, development, division and differentiation of cells. In addition, $\mathrm{Fe}$ is characteristic for its ability to undergo oxidation-reduction reaction and to form a component of chlorophyll. Mn influences directly the indole acetic acid balance in plants, responsible for plant height. 
Abdo, Fatma, A. and Sabah M. Attia 
J. Agric. Sci. Mansoura Univ., 33 (8), August, 2007

3

5779 
Abdo, Fatma, A. and Sabah M. Attia

4

5780 
From the aforementioned results, the enhancing effect of trace elements on dry matter accumulation of shoot can be attributed to their effective physiological role in increasing plant values (Tables 2, 3 and 4). These results are in agreement with those obtained by Gangwar and Singh (1994) on lentil and Waly (1996) on pea.

Finally, foliar spray with $\mathrm{Fe}$ and $\mathrm{Mn}$ attains a suitable balance between these elements that is required to achieve better growth, stronger and more healthy plants in comparison with other methods.

\section{B- Photosynthetic pigments and micronutrients content in leaves:}

Data concerning the effect of application methods of $\mathrm{Fe}$ and $\mathrm{Mn}$ on the content of photosynthetic pigments and $\mathrm{Fe}$ or $\mathrm{Mn}$ in faba bean leaves at the age of 80 days are presented in Table (5).

\section{Photosynthetic pigments:}

Data in Table (5) indicate that no significant effect between two cultivars under study.

These results showed that all photosynthetic pigments (chl. $a$ \& $b$ and carotenoides) were significantly increased by different treatments. In this respect, spraying method attained the highest increase compared to the other methods of application. The enhancing effect of micronutrients addition on the content of photosynthetic pigments of faba bean leaves could be explained by its beneficial effects on the number of chloroplasts per cell or by forming chloroplasts with a high chlorophyll content (Hassan, 1996). At the same time, the superior impact of Fe treatments might be due to the essential roles of $\mathrm{Fe}$ in the redox reactions of chloroplasts, in the mechanism of photosynthetic electron transfer and also in the formation of heme and nonheme proteins, concentrated in chloroplasts. Numerous investigators reached to the same conclusion, e.g. Iturbe-Ormaetxe et al. (1995) on maize and pea, Waly (1996) on pea and Nassar et al. (2002 a) on faba bean.

The interaction between cultivars and application methods on carotenoides was found to be significant. The use of spraying method with Nobaria 1 surpassed Giza 40 cultivar. In this regard, El-Mansi et al. (1991) and Nenova (2006) reported that foliar application of $\mathrm{Fe}$ increased photosynthetic pigments in faba bean leaves.

\section{Micronutrients:}

Data presented in Table (5) clearly show that the difference between the two investigated faba bean cultivars was not significant. Whereas, most of the tested treatments had superior effect on increasing $\mathrm{Fe}$ or $\mathrm{Mn}$ in leaves when compared to control.

As to the effect of application methods, foliar spraying gave the highest increase of $\mathrm{Fe}$ and $\mathrm{Mn}$ contents in leaves by 11.75 and $8.9 \%$ more than coating method and by 6.6 and $4.8 \%$ more than combined method of coating + foliar spraying, respectively.

In this respect, El-Gyar et al. (1988) on faba bean, stated that Fe had a stimulating effect on metabolic process through its direct effect on the enzymatic reactions. Likewise, Ghaly et al. (1992) on lentil and Nassar et al. (2002 a) on faba bean observed that $\mathrm{Fe}$ and Mn applications had positive effect on $\mathrm{Mn}$ and $\mathrm{Fe}$ contents in leaves, being in agreement with the present findings. 
The effect of all studied interactions were not significant on Fe and $\mathrm{Mn}$ contents in leaves of the two studied cultivars.

Table 5. Photosynthetic pigments, iron and manganese of two faba bean cultivars at the age of 80 days as affected by application methods of micronutrients in the second season of 2005 / 2006.

\begin{tabular}{|c|c|c|c|c|c|}
\hline \multirow{2}{*}{ cultivar } & \multirow{2}{*}{$\begin{array}{l}\text { Micronutrients } \\
\text { treatment }\end{array}$} & \multicolumn{2}{|c|}{$\begin{array}{c}\text { Photosynthetic pigments } \\
\text { mg/g fresh weight }\end{array}$} & \multirow{2}{*}{$\begin{array}{l}\text { Fe } \\
\text { ppm }\end{array}$} & \multirow{2}{*}{$\begin{array}{l}\text { Mn } \\
\text { ppm }\end{array}$} \\
\hline & & $\begin{array}{c}\text { Total } \\
\text { chlorophyll }\end{array}$ & Caroteoides & & \\
\hline \multirow{8}{*}{ Giza 40} & Control & 3.840 & 0.564 & 306.2 & 209.4 \\
\hline & Coating & 4.524 & 0.695 & 338.7 & 228.2 \\
\hline & Spray & 4.965 & 0.732 & 394.6 & 233.5 \\
\hline & Coating + Spray & 4.755 & 0.689 & 358.2 & 230.1 \\
\hline & Mn Coating & 4.150 & 0.700 & 316.3 & 274.4 \\
\hline & Spray & 4.773 & 0.708 & 330.4 & 299.5 \\
\hline & Coating + Spray & 4.668 & 0.714 & 327.6 & 297.1 \\
\hline & Mean & 4.525 & 0.686 & 338.86 & 253.17 \\
\hline \multirow{8}{*}{ Nubaria 1} & Control & 3.760 & 0.547 & 330.2 & 220.1 \\
\hline & Coating & 4.523 & 0.688 & 366.5 & 244.0 \\
\hline & Spray & 4.719 & 0.791 & 430.5 & 274.0 \\
\hline & Coating + Spray & 4.646 & 0.663 & 390.0 & 236.2 \\
\hline & Mn Coating & 4.180 & 0.707 & 337.3 & 296.3 \\
\hline & Spray & 4.595 & 0.733 & 362.8 & 328.6 \\
\hline & Coating + Spray & 4.552 & 0.700 & 348.6 & 320.4 \\
\hline & Mean & 4.425 & 0.690 & 366.56 & 274.23 \\
\hline \multirow{7}{*}{$\begin{array}{l}\text { General means } \\
\text { of micronutri- } \\
\text { ents treatment }\end{array}$} & Control & 3.800 & 0.556 & 318.20 & 214.8 \\
\hline & Fe Coating & 4.524 & 0.692 & 352.60 & 236.1 \\
\hline & Spray & 4.842 & 0.762 & 412.55 & 253.8 \\
\hline & Coating + Spray & 4.701 & 0.676 & 374.10 & 233.2 \\
\hline & Mn Coating & 4.165 & 0.704 & 326.80 & 285.4 \\
\hline & Spray & 4.684 & 0.721 & 346.60 & 314.1 \\
\hline & Coating + Spray & 4.610 & 0.707 & 338.10 & 308.8 \\
\hline \multirow{3}{*}{$\begin{array}{c}\text { General means } \\
\text { of application }\end{array}$} & Coating & 4.344 & 0.698 & 339.7 & 260.7 \\
\hline & Spray & 4.763 & 0.741 & 379.6 & 283.9 \\
\hline & Coating + Spray & 4.655 & 0.692 & 356.1 & 271.0 \\
\hline \multicolumn{6}{|c|}{ L.S.D. (0.05) For : } \\
\hline \multicolumn{2}{|c|}{ Cultivar $\quad(\mathrm{A})$} & NS & NS & NS & NS \\
\hline \multicolumn{2}{|c|}{\begin{tabular}{|ll} 
Treatment & (B)
\end{tabular}} & 0.36 & 0.025 & 21.24 & 25.25 \\
\hline \multicolumn{2}{|c|}{ Interaction $\quad(\mathrm{A} \times \mathrm{B})$} & NS & 0.035 & NS & NS \\
\hline \multicolumn{2}{|c|}{\begin{tabular}{|ll} 
Method & (C) \\
\end{tabular}} & 0.26 & 0.013 & 15.02 & 17.85 \\
\hline \multicolumn{2}{|c|}{ Treated vs untreated (D) } & $\star *$ & ** & ** & ** \\
\hline \multicolumn{2}{|c|}{ Interaction $\quad(\mathbf{A} \times \mathbf{C})$} & NS & 0.025 & NS & NS \\
\hline Interaction & $(A \times D)$ & NS & NS & NS & NS \\
\hline
\end{tabular}

${ }^{*},{ }^{\star \star}$ and NS indicate significant at $0.05,0.01$ and insignificant, respectively.

\section{C- Yield and yield components:}

Data given in Table (6) clearly show that Nubaria 1 cultivar was significantly lower than Giza 40 in number of pods / plant. By contrast, Nubaria 1 surpassed significantly Giza 40 in 100-seed weight, seed weight / plant, seed yield / feddan and straw yield / feddan in combined analysis of both seasons. 
J. Agric. Sci. Mansoura Univ., 33 (8), August, 2007 6 


\section{Abdo, Fatma, A. and Sabah M. Attia}

As to the effect of treatments, it is obvious that any of the assigned treatments induced significant increase over the control plants in all investigated yield traits in each season and in combined analysis. The higher values in most investigated yield traits in combined analysis of both seasons were obtained by foliar application with $\mathrm{Fe}$, being in average 20.4, 42.8, 14.2 and $23.2 \%$ more than the control for number of pods / plant, seed weight / plant, 100-seed weight and seed yield / feddan; respectively. Whereas, straw yield / feddan was increased significantly by $23.2 \%$ more than the control when plants were sprayed by $\mathrm{Fe}$ and the significant increase over the control was $23.5 \%$ when plants were sprayed by $\mathrm{Mn}$. Worthy to note that the difference between these two treatments proved insignificant with respect to straw yield / feddan.

It is noted that spraying method for micronutrients application was significantly superior in its response compared to the other two methods of application; i.e., coating method and the combined treatment (coating + spraying). Thus, methods of applying micronutrients could be arranged in descending order with respect to its response as follows: spraying > coating > coating + spraying.

These results are in full agreement with those reported by El-Mansi et. al. (1991) and Abido et al. (1995).

The enhancing effect of the investigated elements on the number of pods / plant may be attributed to changes induced by these nutrients in the endogenous hormone ratios, which led to reduce in shedding percentage and increase setting percentage (Ibrahim and Shalaby, 1994 and Nassar et al., $2002 \mathrm{~b})$. The increase of both the seed index (100-seed weight) and the seed weight / plant may be due to these elements enabling the plants to grow well and to improve the transfer of the photosynthetic substance from leaves to seeds during the synthesis processes, because of their effects on the enzymatic group. Consequently, the weight of seeds increased, according to Nassar et. al. (2002 b) on faba bean. The superior effect of Fe treatments, compared to $\mathrm{Mn}$, is in agreement with that obtained by many investigators such as El-Gyar et. al. (1988) on faba bean plants.

The interaction effect between cultivars and micronutrient treatments (Table 6) had a significant effect on all yield characters. Highest values for yield traits of the two cultivars were recorded with foliar application with $\mathrm{Fe}$ and the difference between spraying $\mathrm{Fe}$ and spraying Mn proved significant in No. of pods / plant, seed weight / plant and seed yield / feddan. Likewise, 100 -seed weight gave higher value when faba bean plants cv. Nubaria 1 were sprayed with $\mathrm{Fe}$ although the difference between foliar application with $\mathrm{Mn}$ and foliar application with Fe was not significant. At the same time, straw yield / feddan of Nubaria 1 recorded significant increase with $\mathrm{Mn}$ and the difference between spraying Mn or Fe proved significant.

Regarding the interaction between cultivars and application methods, data presented in Table (7) proved significant effect on all yield and yield components except No. of pods / plant where the differences were not significant. Foliar spray was the most effective method of application for improving yield and yield components. 
J. Agric. Sci. Mansoura Univ., 33 (8), August, 2007

7 
Such improvement in yield traits of the investigated faba bean cultivars due to micronutrients spray was found to be significant over the other methods of application.

The positive effects of the micronutrients under investigation on both seed and straw yields can be explained as follows:

1. Seed yield is a function of the number of pods, seed weight / plant and 100 -seed weight. These parameters are positively affected by micronutrients addition (Table 6). Hence, yield is also increased. Likewise, straw yield is a product of plant height, so, straw yield increased.

2. Fe and $\mathrm{Mn}$ are involved directly or indirectly in formation of starch, protein and other biological components in faba bean seeds through their role in the respiratory and photosynthesis mechanisms, as well as their roles in the activity of various enzymes (Monged et. al., 1992).

3. These micronutrients play important roles in stimulating the vegetative growth through increasing cell size and leaf area. Thus, the rate of photosynthesis increase (Mahmoud et. al., 1987).

4. The aforementioned trace elements delay the senescence of plants through raising the level of IAA, chlorophyll content and native assimilation ratio (NAR) in leaves. Thus, total dry matter accumulation and yield components increase (Nassar et. al., 2002 b).

D. Certain chemical constituents of the seed (seed quality):

Data in Table (8) revealed that Nubaria 1 cultivar surpassed significantly Giza 40 in seed crude protein by $7.78 \%$. Meanwhile, the difference in total carbohydrates between the two investigated faba bean cultivars was not significant.

Concerning the effect of treatments, it is evident that all treatments surpassed control with significant differences.

As for the effect of application methods, it was found that foliar application of either $\mathrm{Fe}$ or $\mathrm{Mn}$ gave the best values for crude protein and total carbohydrates. The increases due to foliar spray than coating or coating + spray were 4.8 and $3.9 \%$, respectively for crude protein and 6.1 and $5.5 \%$, respectively for total carbohydrates.

The interaction between cultivars and treatments or application methods on protein and total carbohydrates were not significant. The present results are in line with those reported by Rizk and Abdo (2001). They indicated that foliar application with micronutrient increased protein content of mungbean seeds.

Results in Table (8) clearly show that faba bean cv. Nubaria 1 surpassed significantly Giza 40 with respect to micronutrient contents of the seed. The increment over Giza 40 cultivar was $5.87 \%$ for Fe content and it was $9.30 \%$ for Mn content.

Data also revealed that any of the assigned treatment surpassed control with respect to micronutrients contents in seed of the two investigated faba bean cultivars. The higher values of $\mathrm{Fe}$ and $\mathrm{Mn}$ were achieved when plants were sprayed with Fe being 24.4 and $25.5 \%$ more than the control, respectively. 
Regarding the effect of application methods, it was noted that foliar application method with the micronutrients gave the best values of $\mathrm{Fe}$ and $\mathrm{Mn}$ contents in faba bean seeds. The increment due to foliar application method compared to coating or coating + spraying were 11.1 and $7.5 \%$ for $\mathrm{Fe}$ and 10.4 and $7.2 \%$ for $\mathrm{Mn}$, respectively.

The interaction between cultivars and treatments or application methods on $\mathrm{Fe}$ and $\mathrm{Mn}$ content of seed were not significant.

Table 8. Seed quality of two faba bean cultivars as affected by application methods of micronutrients in the second season of 2005 / 2006.

\begin{tabular}{|c|c|c|c|c|c|}
\hline Cultivar & $\begin{array}{l}\text { Micronutrients } \\
\text { treatment }\end{array}$ & $\begin{array}{c}\text { Crude } \\
\text { protein } \\
\% \\
\end{array}$ & $\begin{array}{c}\text { Total } \\
\text { Carbohydreate } \\
\%\end{array}$ & $\begin{array}{c}\mathrm{Fe} \\
\mathrm{mg} / \mathrm{kg}\end{array}$ & $\begin{array}{c}\mathrm{Mn} \\
\mathrm{mg} / \mathbf{k g}\end{array}$ \\
\hline \multirow{8}{*}{ Giza 40} & Control & 22.79 & 51.52 & 207.6 & 104.2 \\
\hline & Coating & 24.64 & 56.15 & 233.9 & 118.4 \\
\hline & Spray & 26.49 & 57.05 & 256.3 & 131.6. \\
\hline & Coating + Spray & 25.34 & 55.03 & 241.5 & 122.9 \\
\hline & Mn Coating & 24.55 & 55.12 & 229.2 & 116.1 \\
\hline & Spray & 25.63 & 61.03 & 243.6 & 124.2 \\
\hline & Coating + Spray & 24.33 & 55.32 & 234.2 & 118.7 \\
\hline & Mean & 24.82 & 55.89 & 235.2 & 119.4 \\
\hline \multirow{8}{*}{ Nubaria 1} & Control & 23.72 & 52.24 & 223.7 & 115.8 \\
\hline & Fe $\quad$ Coating & 26.82 & 55.25 & 241.3 & 128.2 \\
\hline & Spray & 28.22 & 57.37 & 280.4 & 144.6 \\
\hline & Coating + Spray & 27.66 & 56.64 & 253.9 & 132.7 \\
\hline & Mn Coating & 26.87 & 54.55 & 236.4 & 125.4 \\
\hline & Spray & 27.49 & 59.14 & 264.7 & 138.4 \\
\hline & Coating + Spray & 26.45 & 55.39 & 242.8 & 128.5 \\
\hline & Mean & 26.75 & 55.80 & 249.0 & 130.5 \\
\hline \multirow{7}{*}{$\begin{array}{l}\text { General } \\
\text { means of } \\
\text { micronutri- } \\
\text { ents } \\
\text { treatment }\end{array}$} & \begin{tabular}{l|l} 
Control &
\end{tabular} & 23.26 & 51.88 & 215.7 & 110.0 \\
\hline & Coating & 25.73 & 55.70 & 237.6 & 123.3 \\
\hline & Spray & 27.36 & 57.21 & 268.4 & 138.1 \\
\hline & Coating + Spray & 26.50 & 55.84 & 247.7 & 127.8 \\
\hline & Mn Coating & 25.71 & 54.84 & 232.8 & 120.8 \\
\hline & Spray & 26.56 & 60.09 & 254.2 & 131.3 \\
\hline & Coating + Spray & 25.39 & 55.36 & 238.5 & 123.6 \\
\hline \multirow{3}{*}{$\begin{array}{c}\text { General } \\
\text { means of } \\
\text { application }\end{array}$} & Coating & 25.72 & 55.27 & 235.2 & 122.0 \\
\hline & Spray & 26.96 & 58.65 & 261.3 & 134.7 \\
\hline & Coating + Spray & 25.95 & 55.60 & 243.1 & 125.7 \\
\hline \multicolumn{6}{|c|}{ L.S.D. (0.05) For : } \\
\hline \multicolumn{2}{|c|}{ Cultivar $\quad$ (A) } & ** & NS & * & * \\
\hline \multicolumn{2}{|l|}{ Treatment } & 0.56 & 2.55 & 15.68 & 9.58 \\
\hline \multicolumn{2}{|l|}{ Interaction } & NS & NS & NS & NS \\
\hline \multicolumn{2}{|c|}{ Method $\quad$ (C) } & 0.39 & 1.80 & 11.12 & 6.72 \\
\hline \multicolumn{2}{|c|}{ Treated vs untreated (D) } & ** & ** & * & * \\
\hline \multicolumn{2}{|c|}{\begin{tabular}{|ll} 
Interaction & $(\mathrm{A} \times \mathrm{C})$ \\
\end{tabular}} & NS & NS & NS & NS \\
\hline \multicolumn{2}{|l|}{ Interaction } & * & NS & * & * \\
\hline
\end{tabular}

${ }^{*},{ }^{* \star}$ and NS indicate significant at $0.05,0.01$ and insignificant, respectively. 
Finally, it could be stated that foliar application of either Fe or Mn enables the plants to grow well and to absorb more nutrient directly from the leaves, as well as to produce higher seed yield with better quality.

\section{REFERENCES}

Abdel-Aziz, El-Set. A. and N.A. Anton (1999). Influence of applying methods and micronutrients on growth, yield and quality of faba bean. Zagazig $\mathrm{J}$. Agric. Res. , 26 (5) : $1245-1257$.

Abido, Y.M.Y. ; A.A. Abd-El-Magid and Nadia O. Monged (1995). Field trials on faba bean fertilization with some micronutrients. Egypt. J. Appl. Sci., $10(5): 1$ - 14.

A.O.A.C., (1990). Official Methods of Analysis 15th , Ed., Association of Official Agricultural Chemists, Washington, D.C., USA.

Arnon, D.I. (1949). Copper enzymes in isolated chloroplasts polyphenoloxidase in Beta Vulgaris. Plant physiology, 24 (1) : $1-15$.

Azer, S.A. ; A.O. Osman and S. Ghaly (1992). Effect of Mn seed coating of leguminous crops on growth and yield. Egypt. J. Agric. Res., 70 (4) : 989 $-996$.

Chapman, H.D. and P.E. Pratt (1961). Methods of Analysis for Soils. Plant and Waters. Univ. of California, Division of Agric. Sci. p 60 - 69.

Cottenie, A. ; M. Verloo ; L. Kiekens ; G. Velghe and R. Camerlynck (1982). Chemical Analysis of Plant and Soils. Lab. Anal Agroch., Fac. Agric. State Univ. Ghent, Belgium.

Dubois, M. ; K.A. Gilles ; J.K. Hamilton ; P.A. Rebers and F. Smith (1956). Colorimetric Method For Determination of Sugars and Related Substances. Analytical Chemistry, 28 ( 3 ) : $350-356$.

El-Gyar, M.A. ; A.O. Osman ; M.A. Hegab and S.A. Ali (1988). Influence of potassium and chelated iron fertilizers on yield component and elements content in seeds of field bean (Vicia faba L.) in calcareous soils. Annals of Agric. Sci., Moshtohor, 26 (4) : 2285 - 2299.

El-Mansi, A.A. ; M.A. Khalil ; E.A. El-Ghamriny and F.H. Afia (1991). Effect of foliar spray with zinc, manganese and iron on growth and yield of broad bean plants. Zagazig J. Agric. Res. , 18 (6) : 1947 - 1958.

Gangwar, K.S. and N.P. Singh (1994). Studied on zinc nutrition on lentil in relation to dry matter accumulation, yield and NP uptake. Indian J. of Pulses Res., 7 (1) : 33 - 39. [C.F. Field Crop Abst., 48 (10), 7561, 1995].

Ghaly, S. ; A.O. Osman and I.M. Abd El-Aziz (1992). The interaction of some micronutrients and Rhizobium on lentil yield grown on sandy soils. Egypt J. Agric. Res., 70 (4) : 1025 - 1035.

Hassan, Amira H.M. (1996). Biochemical studies on the role of some micronutrients on some monocotyledons. M. Sc. Thesis, Fac. of Agric., Cairo Univ., Egypt.

Hegazy, M.H. ; Dawlat N. Abadi and S.A. Genaidy (1992). Effects of some micronutrients and methods of application and Rhizobium inoculation on faba bean. Egypt. J. Agric. Res., 70 (4) : 1011 - 1023. 
Ibrahim, M.E and M.H. Shalaby (1994). Effect of some micronutrients and methods of their application on growth, yield and mineral composition of wheat. Annals of Agric. Sci., Moshtohor, 32 (3) : $1371-1388$.

Iturbe-Ormaetxe, I. ; J.F. Moran ; C. Arrese Igor ; Y. Gogarcena ; R.V. Klucas and M. Bacha (1995). Activated oxygen and antioxidant defences in iron deficient pea plants. Plant Cell and Environment, 18 (4) : 421 - 429.

Jackson, M.L. (1967). Soil Chemical Analysis. New Delhi, Prentice Hall of India Private Limited, New Delhi. p. 326 - 338.

Mahmoud, M.H. ; I. Abd El-Aziz ; A. El-Sayed and M.A. Ashoub (1987). Effect of soil and foliar application of zinc on yield component and mineral content of two varieties of barley in different soils. Annals of Agric. Sci., Ain Shams Univ., 32 (1): $199-210$.

Monged, N.O. ; M.S. Baza and T.A. Abo-Erdefan (1992). Effect of some micronutrients on faba bean yield under four governorates in A.R.E. Egypt. J. Appl. Sci., 7 (4) : $597-601$.

Nassar, K.E. ; S.A. Radwan and A.A. Rahmou (2002 a). Effect of seed coating with some micronutrients on faba bean (Vicia faba L.). I- Effect on photosynthetic pigments, micronutrient contents and plant growth characters. Egypt . J. of Soil Sci., 42 (2) : $347-362$.

Nassar, K.E. ; A.O. Osman ; M.H. El-Kholy and M.M. Badran (2002 b). Effect of seed coating with some micronutrients on faba bean (Vicia faba L.). IIEffect on yield, yield attributes and mineral composition. Egypt . J. of Soil Sci., 42 (3) : $363-381$.

Nenova, V. (2006). Effect of iron supply on growth and photosystem II efficiency of pea plants. Gen. Appl. Plant Physiology, Special Issue, 81 90.

Osman, A.O. ; M.A. Eskarous and W.E. Ahmed (1992). The interactions of some micronutrients and Rhizobia on faba bean yield grown on sandy soil. Egypt. J. Agric. Res., 70 (3) : 693 - 702.

Rizk, W.M. and F.A. Abdo (2001). The response of two mungbean cultivars to zinc, manganese and boron. II- yield and chemical composition of seeds. Bull. Fac. Agric. Cairo Univ., 52 (3) : 467 - 478.

Steel, R.G. and J.A. Torrie (1980). Principles and Procedure of Statistics. 2nd Ed., McGrow Hill Pub. Co., 633 pp.

Waly, Amal F.A. (1996). Effect of some micronutrients on biochemical components of some plants. M. Sc. Thesis, Fac. of Agric., Cairo Univ., Egypt. 
تأثثير نمو ومحصول الفول البلاى بطرق إضافة الحديد أو المنجنيز

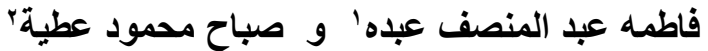
اـ قسم بحوث فسيولوجيا المحاصيل.- معهز بحوث المحاصيل الحقلية ـ مركز البحوث الزراعية

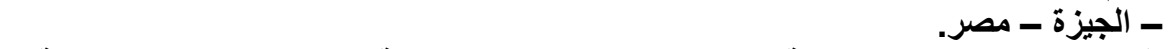
rـ قسم بحوث المحاصيل البقوليةـ معهل بحوث المحاصيل الحقلية ـ مركز البحوث الزراعية ـ

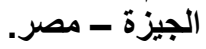

أجريت تجربة حقلية بمحطة البحوث الزر اعية ـ مركز البحوث الزر اعية بالجيزة ، خلال

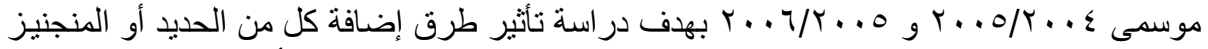

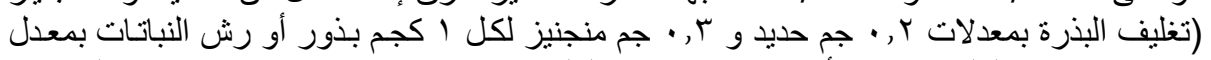

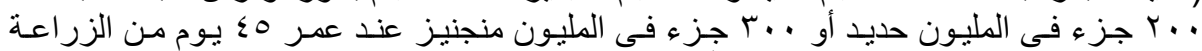

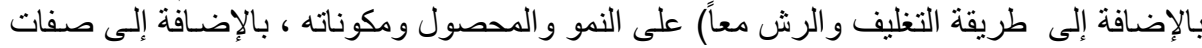

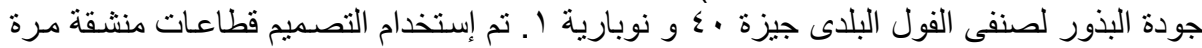

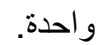

وفيما يلى أهم النتائج المتحصل عليها :

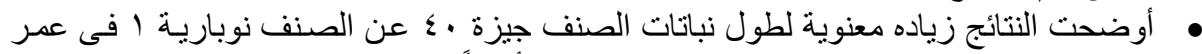

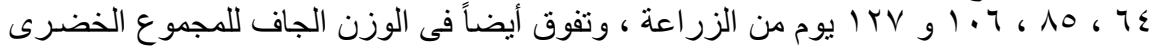

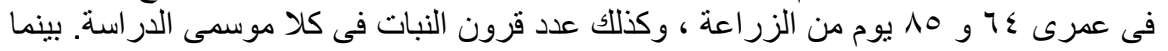

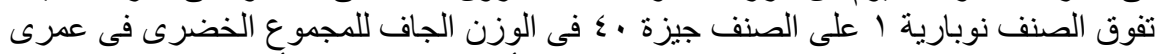

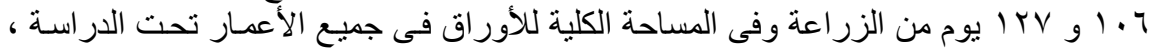

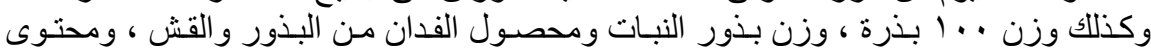
البذور من البروتين الخام و الحديد و المنجنيز.

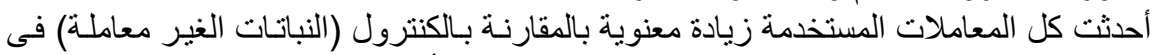

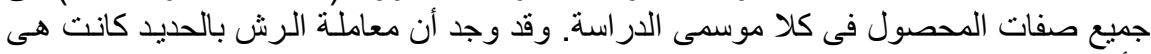

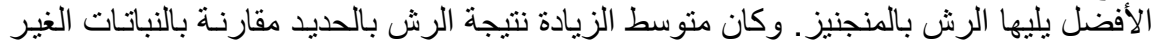

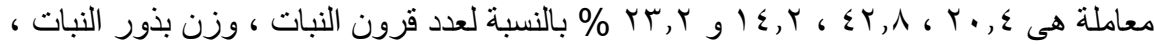

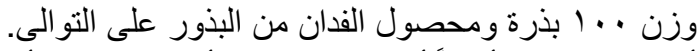

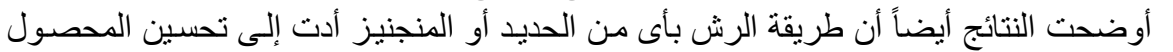

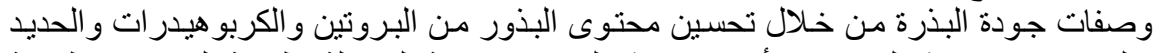

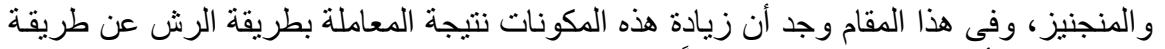

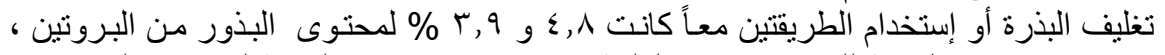

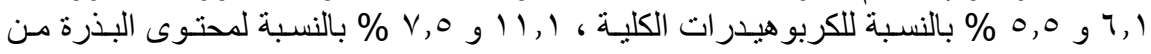

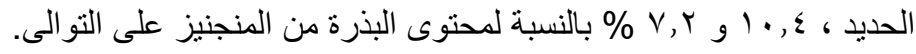


Table 2 : Plant height $(\mathrm{cm})$ of two faba bean cultivars at different ages as affected by application methods of micronutrients in 2004/2005 and 2005/2006 seasons and its combined.

\begin{tabular}{|c|c|c|c|c|c|c|c|c|c|c|c|c|c|}
\hline \multirow[b]{2}{*}{ Cultivar } & \multirow{2}{*}{$\begin{array}{c}\text { Micronutrients } \\
\text { treatment }\end{array}$} & \multicolumn{3}{|c|}{64 days } & \multicolumn{3}{|c|}{85 days } & \multicolumn{3}{|c|}{106 days } & \multicolumn{3}{|c|}{127 days } \\
\hline & & $\begin{array}{c}1^{\text {st }} \\
\text { season }\end{array}$ & $\begin{array}{c}2^{\text {nd }} \\
\text { season }\end{array}$ & Comb. & $\begin{array}{c}1^{\text {st }} \\
\text { season }\end{array}$ & $\begin{array}{c}2^{\text {nd }} \\
\text { season }\end{array}$ & Comb. & $\begin{array}{c}1^{1^{\text {st }}} \\
\text { season }\end{array}$ & $\begin{array}{c}2^{\text {nd }} \\
\text { season }\end{array}$ & Comb. & $\begin{array}{c}1^{\text {st }} \\
\text { season }\end{array}$ & $\begin{array}{c}2^{\text {nd }} \\
\text { season }\end{array}$ & Comb. \\
\hline \multirow{8}{*}{ Giza 40} & Control & 57.4 & 66.7 & 62.05 & 73.3 & 84.5 & 78.90 & 94.7 & 107.8 & 101.25 & 108.2 & 120.9 & 114.55 \\
\hline & Coating & 67.7 & 77.4 & 72.55 & 88.3 & 104.2 & 96.25 & 109.4 & 126.5 & 117.95 & 126.7 & 136.7 & 131.70 \\
\hline & Spray & 71.3 & 80.5 & 75.90 & 94.9 & 108.6 & 101.75 & 118.5 & 133.2 & 125.85 & 131.6 & 141.4 & 136.50 \\
\hline & Coating + Spray & 66.6 & 75.4 & 71.00 & 87.7 & 102.7 & 95.20 & 107.9 & 120.9 & 114.40 & 122.8 & 130.6 & 126.70 \\
\hline & Mn $\quad$ Coating & 67.3 & 75.9 & 71.60 & 88.6 & 98.9 & 93.75 & 111.1 & 121.4 & 116.25 & 124.6 & 131.2 & 127.90 \\
\hline & Spray & 69.4 & 78.0 & 73.70 & 90.9 & 101.4 & 96.15 & 113.2 & 127.5 & 120.35 & 128.4 & 136.5 & 132.45 \\
\hline & Coating + Spray & 65.3 & 73.7 & 69.50 & 84.5 & 94.8 & 89.65 & 104.8 & 120.2 & 112.50 & 121.1 & 128.4 & 124.75 \\
\hline & Mean & 66.43 & 75.37 & 70.90 & 86.89 & 99.30 & 93.09 & 108.51 & 122.5 & 115.51 & 123.34 & 132.24 & 127.79 \\
\hline \multirow{8}{*}{ Nubaria 1} & Control & 39.6 & 45.8 & 42.70 & 60.2 & 68.6 & 64.40 & 81.8 & 91.3 & 86.55 & 91.4 & 99.7 & 95.55 \\
\hline & Fe $\quad$ Coating & 47.6 & 54.0 & 50.80 & 69.7 & 80.1 & 74.90 & 95.9 & 107.7 & 101.80 & 107.9 & 113.3 & 110.60 \\
\hline & Spray & 50.4 & 56.9 & 53.65 & 74.3 & 86.2 & 80.25 & 104.5 & 113.5 & 109.00 & 113.5 & 117.5 & 115.50 \\
\hline & Coating + Spray & 46.5 & 51.7 & 49.10 & 69.3 & 77.7 & 73.50 & 91.2 & 102.4 & 96.80 & 103.3 & 106.2 & 104.75 \\
\hline & Mn Coating & 45.8 & 50.9 & 48.35 & 68.4 & 76.9 & 72.65 & 95.4 & 100.2 & 97.80 & 102.5 & 107.5 & 105.00 \\
\hline & Spray & 49.1 & 54.3 & 51.70 & 73.1 & 80.4 & 76.75 & 102.2 & 109.8 & 106.00 & 109.3 & 114.7 & 112.00 \\
\hline & Coating + Spray & 44.8 & 50.3 & 47.55 & 66.9 & 74.3 & 70.60 & 93.4 & 101.5 & 97.45 & 100.8 & 107.3 & 104.05 \\
\hline & Mean & 46.26 & 51.99 & 49.12 & 68.84 & 77.74 & 73.29 & 94.91 & 103.77 & 99.34 & 104.1 & 109.46 & 106.78 \\
\hline \multirow{7}{*}{$\begin{array}{l}\text { General } \\
\text { means of } \\
\text { micronut- } \\
\text { rients } \\
\text { treatment }\end{array}$} & Control & 48.50 & 56.25 & 52.38 & 66.75 & 76.55 & 71.65 & 88.25 & 99.55 & 93.90 & 99.80 & 110.30 & 105.05 \\
\hline & Fe $\quad$ Coating & 57.65 & 65.70 & 61.68 & 79.00 & 92.15 & 85.58 & 102.65 & 117.10 & 109.88 & 117.30 & 125.00 & 121.15 \\
\hline & Spray & 60.85 & 68.70 & 64.78 & 84.60 & 97.40 & 91.00 & 111.50 & 123.35 & 117.43 & 122.55 & 129.45 & 126.00 \\
\hline & Coating + Spray & 56.55 & 63.55 & 60.05 & 78.50 & 90.20 & 84.35 & 99.55 & 111.65 & 105.60 & 113.05 & 118.40 & 115.73 \\
\hline & Mn Coating & 56.55 & 63.40 & 59.98 & 78.50 & 87.90 & 83.20 & 103.25 & 110.80 & 107.03 & 113.55 & 119.35 & 116.45 \\
\hline & Spray & 59.25 & 66.15 & 62.70 & 82.00 & 90.90 & 86.45 & 107.70 & 118.65 & 113.18 & 118.85 & 125.60 & 122.23 \\
\hline & Coating + Spray & 55.05 & 62.00 & 58.53 & 75.70 & 84.55 & 80.13 & 99.10 & 110.85 & 98 & 110.95 & 117.85 & 114.40 \\
\hline \multirow{3}{*}{\multicolumn{2}{|c|}{\begin{tabular}{|l|l|} 
General & Coating \\
means of & Spray \\
\cline { 2 - 2 } application & Coating + Spray
\end{tabular}}} & 57.10 & 64.55 & 60.83 & 78.75 & 90.03 & 84.39 & 102.95 & 113.95 & 108.45 & 115.43 & 122.18 & 118.80 \\
\hline & & 60.05 & 67.43 & 63.74 & 83.30 & 94.15 & 88.73 & 109.60 & 121.00 & 115.30 & 120.70 & 127.53 & 124.11 \\
\hline & & 55.80 & 62.78 & 59.29 & 77.1 & 87.38 & 82.24 & 99.33 & 111.25 & 105.29 & 112.00 & 118.13 & 115.06 \\
\hline \multicolumn{14}{|c|}{ L.S.D. (0.05) For : } \\
\hline Cultivar & (A) & ** & ** & ** & $* *$ & ** & ** & 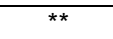 & ** & ** & ** & ** & ** \\
\hline Treatment & (B) & 1.43 & 1.66 & 1.07 & 1.56 & 2.05 & 1.25 & 1.79 & 2.43 & 1.47 & 1.47 & 1.74 & 1.11 \\
\hline Interaction & $(\mathrm{A} \times \mathrm{B})$ & NS & NS & NS & 2.20 & 2.90 & 1.77 & 1.69 & 3.44 & 2.08 & 2.08 & NS & 1.57 \\
\hline Method & (C) & 1.01 & 1.18 & 0.78 & 1.10 & 1.45 & 0.89 & 1.26 & 1.72 & 1.04 & 1.04 & 1.23 & 0.82 \\
\hline Treated vs L & untreated (D) & ** & ** & ** & $* *$ & $\star \star *$ & $* *$ & $\star \star \star$ & ** & ** & $\star \star \star$ & $\star \star \star$ & $\star \star \star$ \\
\hline Interaction & $(\mathrm{A} \times \mathrm{C})$ & NS & NS & NS & NS & NS & NS & NS & NS & NS & NS & NS & NS \\
\hline Interaction & $(\mathrm{A} \times \mathrm{D})$ & & 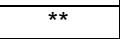 & 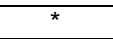 & $\star \star \star$ & 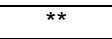 & ** & * & * & * & $* \star$ & * & \\
\hline
\end{tabular}

* ${ }^{* \star}$ and NS indicate significant at $0.05,0.01$ and insignificant, respectively. 
Table 3 : Shoot dry weight (g) of two faba bean cultivars at different ages as affected by application methods of micronutrients in 2004/2005 and 2005/2006 seasons and its combined.

\begin{tabular}{|c|c|c|c|c|c|c|c|c|c|c|c|c|c|}
\hline \multirow[b]{2}{*}{ Cultivar } & \multirow[b]{2}{*}{$\begin{array}{l}\text { Micronutrients } \\
\text { treatment }\end{array}$} & \multicolumn{3}{|c|}{64 days } & \multicolumn{3}{|c|}{85 days } & \multicolumn{3}{|c|}{106 days } & \multicolumn{3}{|c|}{127 days } \\
\hline & & $\begin{array}{c}1^{\text {st }} \\
\text { season }\end{array}$ & \begin{tabular}{c|}
$2^{\text {nd }}$ \\
season
\end{tabular} & Comb. & $\begin{array}{c}1^{\text {st }} \\
\text { season }\end{array}$ & $\begin{array}{c}2^{\text {nd }} \\
\text { season }\end{array}$ & Comb. & $\begin{array}{c}1^{\text {st }} \\
\text { season }\end{array}$ & $\begin{array}{c}2^{\text {nd }} \\
\text { season }\end{array}$ & Comb. & \begin{tabular}{c|}
$1^{\text {st }}$ \\
season
\end{tabular} & \begin{tabular}{c|}
$2^{\text {nd }}$ \\
season
\end{tabular} & Comb. \\
\hline \multirow{8}{*}{ Giza 40} & Control & 18.93 & 20.74 & 19.84 & 27.48 & 30.39 & 28.94 & 55.29 & 60.11 & 57.7 & 74.91 & 80.71 & 77.81 \\
\hline & Coating & 23.74 & 26.73 & 25.24 & 36.60 & 43.37 & 39.99 & 66.58 & 73.29 & 69.94 & 93.58 & 107.87 & 100.73 \\
\hline & Spray & 25.14 & 28.29 & 26.72 & 38.94 & 46.08 & 42.51 & 72.91 & 80.22 & 76.57 & 101.29 & 115.01 & 108.15 \\
\hline & Coating + Spray & 22.09 & 24.58 & 23.34 & 33.33 & 36.41 & 34.87 & 63.22 & 69.51 & 66.37 & 88.81 & 97.12 & 92.97 \\
\hline & Mn Coating & 24.21 & 27.25 & 25.73 & 36.14 & 40.29 & 38.22 & 66.08 & 71.28 & 68.68 & 89.02 & 98.39 & 93.71 \\
\hline & Spray & 25.46 & 28.48 & 26.97 & 38.42 & 42.01 & 40.22 & 70.11 & 77.71 & 73.91 & 96.81 & 106.32 & 101.57 \\
\hline & Coating + Spray & 22.58 & 23.72 & 23.15 & 31.99 & 35.14 & 33.57 & 64.52 & 68.59 & 66.56 & 84.30 & 91.70 & 88.00 \\
\hline & Mean & 23.16 & 25.68 & 24.42 & 34.70 & 39.10 & 36.90 & 65.53 & 71.53 & 68.53 & 89.82 & 99.59 & 94.71 \\
\hline \multirow{8}{*}{ Nubaria 1} & Control & 17.16 & 18.21 & 17.69 & 24.27 & 26.51 & 25.39 & 62.72 & 68.79 & 65.76 & 85.42 & 92.88 & 89.15 \\
\hline & Coating & 21.21 & 23.56 & 22.39 & 31.50 & 36.77 & 34.14 & 80.59 & 90.91 & 85.75 & 103.61 & 114.71 & 109.16 \\
\hline & Spray & 22.29 & 24.18 & 23.24 & 33.06 & 37.43 & 35.25 & 86.10 & 97.38 & 91.74 & 114.48 & 123.29 & 118.89 \\
\hline & Coating + Spray & 20.13 & 21.76 & 20.95 & 29.00 & 34.25 & 31.63 & 75.08 & 84.22 & 79.65 & 100.69 & 106.21 & 103.45 \\
\hline & $\mathrm{Mn}$ Coating & 20.68 & 22.27 & 21.48 & 29.78 & 32.13 & 30.96 & 78.61 & 87.77 & 83.19 & 103.21 & 113.37 & 108.29 \\
\hline & Spray & 22.08 & 22.98 & 22.53 & 31.65 & 34.04 & 32.85 & 83.49 & 93.41 & 88.45 & 113.11 & 122.21 & 117.66 \\
\hline & Coating + Spray & 19.63 & 21.07 & 20.35 & 28.47 & 30.88 & 29.68 & 73.68 & 82.18 & 77.93 & 100.88 & 108.62 & 104.75 \\
\hline & Mean & 20.45 & 22.00 & 21.23 & 29.68 & 33.14 & 31.41 & 77.18 & 86.38 & 81.78 & 103.06 & 111.61 & 107.34 \\
\hline \multirow{7}{*}{$\begin{array}{l}\text { General } \\
\text { means of } \\
\text { micronut- } \\
\text { rients } \\
\text { treatments }\end{array}$} & Control & 18.05 & 19.48 & 18.77 & 25.88 & 28.45 & 27.17 & 59.01 & 64.45 & 61.73 & 80.17 & 86.80 & 83.49 \\
\hline & $\begin{array}{ll}\text { Fe } & \text { Coating }\end{array}$ & 22.48 & 25.15 & 23.82 & 34.05 & 40.07 & 37.06 & 73.59 & 82.10 & 77.85 & 98.60 & 111.29 & 104.95 \\
\hline & Spray & 23.72 & 26.24 & 24.98 & 36.00 & 41.76 & 38.88 & 79.51 & 88.80 & 84.16 & 107.89 & 119.15 & 113.52 \\
\hline & Coating + Spray & 21.11 & 23.17 & 22.14 & 31.17 & 35.33 & 33.25 & 69.15 & 76.87 & 73.01 & 94.75 & 101.67 & 98.21 \\
\hline & $\begin{array}{|ll|}\text { Mn } & \text { Coating } \\
\end{array}$ & 22.45 & 24.76 & 23.61 & 32.96 & 36.21 & 34.59 & 72.35 & 79.53 & 75.94 & 96.12 & 105.88 & 101.00 \\
\hline & Spray & 23.77 & 25.73 & 24.75 & 35.04 & 38.04 & 36.54 & 76.80 & 85.56 & 81.18 & 104.96 & 114.27 & 109.62 \\
\hline & Coating + Spray & 21.11 & 22.40 & 21.75 & 30.23 & 33.01 & 31.62 & 69.10 & 75.39 & 72 & 92.59 & 100.16 & 96.38 \\
\hline \multirow{4}{*}{\multicolumn{2}{|c|}{\begin{tabular}{|l|l|}
$\begin{array}{l}\text { General } \\
\text { means of } \\
\text { application }\end{array}$ & Coating \\
Spray \\
L.S.D. (0.05) & For :
\end{tabular}}} & 22.46 & 24.95 & 23.72 & 33.51 & 38.14 & 35.83 & 72.97 & 80.81 & 76.89 & 97.36 & 108.59 & 102.98 \\
\hline & & 23.74 & 25.98 & 24.87 & 35.52 & 39.89 & 37.71 & 78.15 & 87.17 & 82.67 & 106.42 & 116.71 & 111.57 \\
\hline & & 21.11 & 22.78 & 21.95 & 30.70 & 34.17 & 32.44 & 69.13 & 76.13 & 72.63 & 93.67 & 100.91 & 97.29 \\
\hline & & & & & & & & & & & & & \\
\hline \multicolumn{2}{|c|}{ Cultivar } & * & ** & . & * & * & * & ** & ** & * & ** & ** & ** \\
\hline \multirow{2}{*}{\begin{tabular}{|l|} 
Treatment \\
Interaction
\end{tabular}} & (B) & 1.02 & 1.10 & 0.73 & 1.05 & 1.36 & 0.76 & 0.82 & 1.37 & 0.78 & 0.91 & 1.74 & 1.84 \\
\hline & $(\mathrm{A} \times \mathrm{B})$ & NS & NS & NS & 1.49 & 1.93 & 1.08 & 1.16 & 1.93 & 1.10 & 1.28 & 2.46 & 1.31 \\
\hline Method & & 0.72 & 0.78 & 0.53 & 0.74 & 0.96 & 0.60 & 0.58 & 0.97 & 0.54 & 0.64 & 1.23 & 0.66 \\
\hline \multicolumn{2}{|c|}{ Treated vs untreated (D) } & $\star \star *$ & ** & $\star \star *$ & ** & ** & ** & $* *$ & $* \star$ & ** & ** & $\star *$ & ** \\
\hline Interaction & $(A \times C)$ & NS & 1.10 & NS & NS & 1.36 & NS & 0.82 & 1.37 & 0.90 & 0.91 & NS & NS \\
\hline Interaction & $(A \times D)$ & NS & NS & NS & * & & & & & & & & \\
\hline
\end{tabular}

* ${ }^{\star \star}$ and NS indicate significant at $0.05,0.01$ and insignificant, respectively. 
Table 4. Total leaf area / plant $\left(\mathrm{d} \mathrm{cm}^{2}\right)$ of two faba bean cultivars at different ages as affected by application methods of micronutrients in 2004/2005 and 2005/2006 seasons and its combined.

\begin{tabular}{|c|c|c|c|c|c|c|c|c|c|c|c|c|c|}
\hline \multirow[b]{2}{*}{ Cultivar } & \multirow[b]{2}{*}{$\begin{array}{l}\text { Micronutrients } \\
\text { treatment }\end{array}$} & \multicolumn{3}{|c|}{64 days } & \multicolumn{3}{|c|}{85 days } & \multicolumn{3}{|c|}{106 days } & \multicolumn{3}{|c|}{127 days } \\
\hline & & $\begin{array}{c}1^{\text {st }} \\
\text { season }\end{array}$ & \begin{tabular}{|c|}
$2^{\text {nd }}$ \\
season
\end{tabular} & Comb. & \begin{tabular}{c|}
$1^{\text {st }}$ \\
season
\end{tabular} & $\begin{array}{c}2^{\text {nd }} \\
\text { season }\end{array}$ & Comb. & \begin{tabular}{|c|}
$1^{\text {st }}$ \\
season \\
\end{tabular} & \begin{tabular}{c|}
$2^{\text {nd }}$ \\
season
\end{tabular} & Comb. & $\begin{array}{c}1^{1^{\text {st }}} \\
\text { season }\end{array}$ & \begin{tabular}{|c|}
$2^{\text {nd }}$ \\
season \\
\end{tabular} & Comb. \\
\hline \multirow{8}{*}{ Giza 40} & Control & 18.32 & 17.82 & 18.07 & 24.99 & 26.51 & 25.75 & 42.19 & 45.21 & 43.70 & 26.38 & 23.52 & 24.95 \\
\hline & \begin{tabular}{ll|} 
Fe & Coating \\
\end{tabular} & 23.76 & 23.66 & 23.71 & 36.04 & 40.72 & 38.38 & 56.32 & 63.16 & 59.74 & 37.04 & 34.64 & 35.84 \\
\hline & Spray & 25.01 & 25.18 & 25.10 & 39.61 & 45.54 & 42.58 & 61.05 & 68.49 & 64.77 & 39.89 & 37.58 & 38.74 \\
\hline & Coating + Spray & 22.02 & 20.76 & 21.39 & 31.71 & 35.11 & 33.41 & 51.22 & 54.48 & 52.85 & 32.66 & 28.51 & 30.59 \\
\hline & Mn Coating & 22.86 & 22.61 & 22.74 & 32.84 & 37.09 & 34.97 & 55.35 & 58.46 & 56.91 & 34.21 & 29.52 & 31.87 \\
\hline & Spray & 24.90 & 23.81 & 24.36 & 35.66 & 40.08 & 37.87 & 63.07 & 73.55 & 68.31 & 36.59 & 32.83 & 34.71 \\
\hline & Coating + Spray & 21.86 & 20.97 & 21.42 & 30.79 & 32.47 & 31.63 & 51.73 & 56.56 & 54.15 & 31.18 & 26.93 & 29.06 \\
\hline & Mean & 22.68 & 22.12 & 22.40 & 33.09 & 36.79 & 34.94 & 54.42 & 59.99 & 57.20 & 33.99 & 30.50 & 32.25 \\
\hline \multirow{8}{*}{ Nubaria 1} & Control & 19.57 & 20.26 & 19.92 & 28.24 & 30.39 & 29.32 & 55.47 & 60.56 & 58.02 & 28.25 & 27.98 & 28.12 \\
\hline & Fe $\quad$ Coating & 25.68 & 27.17 & 26.43 & 38.35 & 42.61 & 40.48 & 76.77 & 87.51 & 82.14 & 38.67 & 39.73 & 39.20 \\
\hline & Spray & 27.52 & 28.26 & 27.89 & 41.29 & 46.71 & 44.00 & 79.04 & 91.20 & 85.12 & 41.08 & 43.28 & 42.18 \\
\hline & Coating + Spray & 23.27 & 24.78 & 24.03 & 34.88 & 38.56 & 36.72 & 68.28 & 74.37 & 71.33 & 34.66 & 36.14 & 35.40 \\
\hline & Mn Coating & 23.97 & 24.27 & 24.12 & 35.50 & 39.14 & 37.32 & 71.89 & 81.33 & 76.61 & 35.74 & 34.53 & 35.14 \\
\hline & Spray & 25.58 & 25.79 & 25.69 & 38.49 & 41.76 & 40.13 & 76.77 & 88.48 & 82.63 & 37.60 & 36.44 & 37.02 \\
\hline & Coating + Spray & 22.86 & 23.98 & 23.42 & 33.78 & 37.56 & 35.67 & 66.40 & 73.22 & 69.81 & 32.99 & 31.53 & 32.26 \\
\hline & Mean & 24.06 & 24.93 & 24.50 & 35.79 & 39.53 & 37.66 & 70.66 & 79.52 & 75.09 & 35.57 & 35.66 & 35.62 \\
\hline \multirow{7}{*}{$\begin{array}{l}\text { General } \\
\text { means of } \\
\text { micronutri- } \\
\text { ents } \\
\text { treatment }\end{array}$} & Control & 18.95 & 19.04 & 19.00 & 26.62 & 28.45 & 27.54 & 48.83 & 52.89 & 50.86 & 27.32 & 25.75 & 26.54 \\
\hline & $\begin{array}{ll}\text { Fe } & \text { Coating } \\
\end{array}$ & 24.72 & 25.42 & 25.07 & 37.20 & 41.67 & 39.44 & 66.55 & 75.34 & 70.94 & 37.86 & 37.19 & 37.52 \\
\hline & Spray & 26.27 & 26.72 & 26.50 & 40.45 & 46.13 & 43.29 & 70.05 & 79.85 & 74.95 & 40.49 & 40.43 & 40.46 \\
\hline & Coating + Spray & 22.65 & 22.77 & 22.71 & 33.30 & 36.84 & 35.07 & 59.75 & 64.43 & 62.09 & 33.66 & 32.33 & 33.00 \\
\hline & Mn $\quad$ Coating & 23.42 & 23.44 & 23.43 & 34.17 & 38.12 & 36.15 & 63.62 & 69.90 & 66.76 & 34.98 & 32.03 & 33.51 \\
\hline & Spray & 25.24 & 24.80 & 25.02 & 37.08 & 40.92 & 39.00 & 69.92 & 81.02 & 75.47 & 37.10 & 34.64 & 35.87 \\
\hline & Coating + Spray & 22.36 & 22.48 & 22.42 & 32.29 & 35.02 & 33.66 & 59.07 & 64.89 & 61.98 & 32.09 & 29.23 & 30.66 \\
\hline \multirow{4}{*}{\multicolumn{2}{|c|}{\begin{tabular}{|l|l|}
$\begin{array}{l}\text { General } \\
\text { means of } \\
\text { application }\end{array}$ & $\begin{array}{l}\text { Coating } \\
\text { Spray }\end{array}$ \\
L.S.D. (0.05) & For :
\end{tabular}}} & 24.07 & 24.43 & 24.25 & 35.68 & 39.89 & 37.80 & 65.08 & 72.62 & 68.85 & 36.42 & 34.61 & 35.52 \\
\hline & & 25.75 & 25.76 & 25.76 & 38.76 & 43.52 & 41.15 & 69.98 & 80.43 & 75.22 & 38.79 & 37.53 & 38.17 \\
\hline & & 22.50 & 22.62 & 22.57 & 32.79 & 35.93 & 34.37 & 59.41 & 64.66 & 62.04 & 32.87 & 30.78 & 31.83 \\
\hline & & & & & & & & & & & & & \\
\hline \multicolumn{2}{|c|}{ Cultivar } & * & * & * & * & ** & * & ** & ** & ** & * & 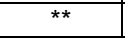 & * \\
\hline \multirow{2}{*}{\begin{tabular}{|l|} 
Treatment \\
Interaction \\
\end{tabular}} & (B) & 0.84 & 0.97 & 0.73 & 0.92 & 1.09 & 0.70 & 1.18 & 0.92 & 0.73 & 0.82 & 0.78 & 0.61 \\
\hline & $(A \times B)$ & NS & NS & NS & 1.31 & 1.55 & 0.98 & 1.67 & 1.29 & 1.03 & 1.18 & 1.10 & 0.86 \\
\hline Method & (C) & 0.59 & 0.69 & 0.45 & 0.65 & 0.77 & 0.51 & 0.83 & 0.65 & 0.82 & 0.58 & 0.55 & 0.41 \\
\hline \multicolumn{2}{|c|}{ Treated vs untreated (D) } & $\star \star \star$ & ** & $\star * *$ & ** & ** & ** & ** & ** & ** & $\star * *$ & & $\hbar \star$ \\
\hline Interaction & $(A \times C)$ & NS & NS & NS & NS & 1.09 & NS & 1.18 & 0.92 & 0.74 & NS & 0.78 & NS \\
\hline Interaction & $(A \times D)$ & NS & NS & NS & NS & NS & NS & 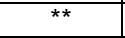 & 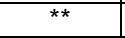 & 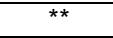 & NS & NS & NS \\
\hline
\end{tabular}


Table 6. Yield traits of two faba bean cultivars as affected by application methods of micronutrients in 2004/2005 and 2005/2006 seasons and its combined.

\begin{tabular}{|c|c|c|c|c|c|c|c|c|c|c|c|c|c|c|c|c|}
\hline \multirow{2}{*}{ Cultivar } & \multirow{2}{*}{$\begin{array}{l}\text { Micronutients } \\
\text { treatment }\end{array}$} & \multicolumn{3}{|c|}{ No. of pods / plant } & \multicolumn{3}{|c|}{ Seed weight / plant } & \multicolumn{3}{|c|}{ 100-seed weight } & \multicolumn{3}{|c|}{$\begin{array}{l}\text { Seed yield / feddan } \\
\text { (ardab) }\end{array}$} & \multicolumn{3}{|c|}{ Straw yield / feddan $(\mathrm{kg})$} \\
\hline & & $\begin{array}{c}1^{\text {st }} \\
\text { season }\end{array}$ & $\begin{array}{c}2^{\text {nd }} \\
\text { season }\end{array}$ & & $\begin{array}{c}1^{\text {st }} \\
\text { season }\end{array}$ & $\begin{array}{c}2^{\text {nd }} \\
\text { season }\end{array}$ & & $\begin{array}{c}1^{\text {st }} \\
\text { season }\end{array}$ & \begin{tabular}{|c|}
$2^{\text {nd }}$ \\
season
\end{tabular} & & $\begin{array}{c}1^{\text {st }} \\
\text { season }\end{array}$ & $\begin{array}{c}2^{\text {nd }} \\
\text { season }\end{array}$ & c & $\begin{array}{c}11^{\text {st }} \\
\text { season }\end{array}$ & \begin{tabular}{|c|}
$2^{\text {nd }}$ \\
season
\end{tabular} & Com \\
\hline \multirow{8}{*}{ Giza 40} & Control & 26.3 & 28.1 & \begin{tabular}{|l|}
27.20 \\
\end{tabular} & 35.96 & 37.86 & 36.91 & 57.44 & \begin{tabular}{|l|}
55.93 \\
\end{tabular} & 56.69 & 10.83 & 11.29 & 11.06 & 1752.2 & \begin{tabular}{|l|}
1879.7 \\
\end{tabular} & 1815.95 \\
\hline & Coating & 30.1 & 31.7 & 30.90 & 46.25 & 45.56 & 4591 & 63.53 & 62.08 & 62.81 & 12.82 & 12.48 & 12.65 & 390.3 & & \\
\hline & Spray & 31.6 & 33.3 & 32.45 & 51.50 & 53.19 & 52.35 & 65.94 & \begin{tabular}{|l|}
63.75 \\
\end{tabular} & 4.85 & & 13.86 & 13.82 & & & \\
\hline & Coating + Spray & 29.8 & 30.9 & \begin{tabular}{|l|}
30.35 \\
\end{tabular} & 44.28 & 45.37 & 44.83 & 62.72 & 61.12 & 61.92 & 12.19 & 12.35 & 12.27 & 1853.6 & 4.2 & 1923.90 \\
\hline & $\begin{array}{|ll|}\text { Mn } & \text { Coating } \\
\end{array}$ & 28.5 & 30.2 & 29.35 & 44.42 & 43.52 & 43.97 & 61.75 & 59.97 & 60.86 & & 12.41 & 12.26 & 1827.0 & & \\
\hline & Spray & 30.4 & 32.1 & 31 & 48.06 & 49.63 & 48.85 & 6151 & & & & & & & & \\
\hline & Coating + Spray & 28.2 & 30.0 & 29.10 & 41.37 & 43.05 & 42.21 & 61.36 & & 61.29 & & 7 & & & & \\
\hline & Mean & 29.27 & 30.9 & \begin{tabular}{|l|}
30.09 \\
\end{tabular} & 44.55 & 45.45 & & 62.46 & & 61.75 & & & & & & \\
\hline \multirow{8}{*}{ Nubaria 1} & & & & & & & & 104 & & & & & & & & \\
\hline & Coating & 19.5 & 21.0 & 20.25 & 72.30 & 82.18 & 77.24 & 116 & & & & & & & & \\
\hline & Spray & 21.1 & 22.1 & 21.60 & 82.48 & 89.27 & 85.88 & 120.85 & \begin{tabular}{|l|}
122.47 \\
\end{tabular} & 121.66 & 8 & 0.44 & 20.06 & 2892.5 & 39.1 & 80 \\
\hline & Coaling +Spray & 18.7 & 20.3 & 19.50 & 68.89 & 77.97 & & & & & & & & & & \\
\hline & Mn Coating & 18.3 & 20.2 & & \begin{tabular}{|l|}
67.67 \\
\end{tabular} & 77.61 & & 114 & & & & & & & & \\
\hline & Spray & 20.2 & 21.3 & 20.75 & 78.25 & 86.74 & 82.50 & 119.31 & 123.12 & 121.22 & & 05 & 19.48 & 3004.8 & 3352.7 & \\
\hline & Coating + Spray & 18.3 & 19.9 & & & & & 113.55 & & & & & & & & \\
\hline & Mea & 19.0 & 20.47 & & & 79.18 & & 115 & & & & & & & & \\
\hline \multirow{7}{*}{$\begin{array}{c}\text { General } \\
\text { means of } \\
\text { micronutr- } \\
\text { ients } \\
\text { treatment }\end{array}$} & Control & 21.60 & 23.30 & 22.45 & 45.82 & 50.96 & 48.39 & 81.08 & 82.26 & 67 & & 14.19 & 13.75 & 2018.2 & & \\
\hline & Coating & 24.80 & \begin{tabular}{l|l}
26.35 \\
\end{tabular} & \begin{tabular}{|l|}
25.58 \\
\end{tabular} & \begin{tabular}{|l|}
59.28 \\
\end{tabular} & \begin{tabular}{|l|}
63.87 \\
\end{tabular} & \begin{tabular}{|l|}
61.58 \\
\end{tabular} & 90.24 & 90.70 & 90.47 & 5.61 & 15.68 & 15.65 & 2270.0 & 2545.8 & 7.88 \\
\hline & Spray & & 27.70 & & & & & & & & & & & & & \\
\hline & Coating +Spray & 24.25 & 25.60 & & 56.59 & 61.67 & & & & & & & & & 2402.3 & \\
\hline & Mn Coating & 23.40 & 25.20 & 24.30 & 56.05 & 60.57 & 58.31 & 88.27 & 88.95 & 88.61 & 14.78 & 15.48 & 15.13 & 2317.6 & 2571.1 & 2444.30 \\
\hline & Spray & 25.30 & 26.70 & 26.00 & 63.16 & 68.19 & 65.68 & 91. & & & & & 16.34 & & 5.5 & 2610.75 \\
\hline & Coading + & & 24.95 & & & 59.74 & & 87. & & & & & & & & \\
\hline \multirow{3}{*}{$\begin{array}{c}\text { General } \\
\text { means of } \\
\text { application }\end{array}$} & Coating & 24.10 & 25.78 & 24.94 & 57.66 & \begin{tabular}{|l|}
62.22 \\
\end{tabular} & 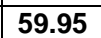 & 89.25 & 3 & 54 & 9 & \begin{tabular}{l|l}
15.58 \\
\end{tabular} & \begin{tabular}{|l|}
15.39 \\
\end{tabular} & 2293.8 & 2558.4 & \\
\hline & Spray & 25.83 & 27.20 & 26.52 & \begin{tabular}{|l|}
65.07 \\
\end{tabular} & 69.71 & 67.39 & 92.65 & 93.13 & 92.89 & & 16.92 & 16.64 & 2466.4 & 2749.4 & 7.90 \\
\hline & Coating+Spray & 23.75 & 25.28 & 24.52 & 55.17 & 60.70 & 57. & 88.23 & 89.82 & 89.03 & & & 15.08 & & & 2353.40 \\
\hline \multicolumn{2}{|c|}{ L.S.D. (0.05) For: } & & & & & & & & & & & & & & & \\
\hline $\mathbf{C}$ & (A) & 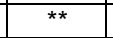 & ** & ** & ** & ** & 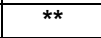 & 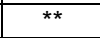 & ** & ** & ** & ** & $\star \star \star$ & $\star \star \star$ & ${ }_{* *}^{* *}$ & 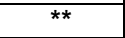 \\
\hline eatment & (B) & 0.45 & 0.84 & & 0.63 & 0.8 & & 0.78 & 0.44 & & & 11 & 4 & 52.18 & 41.53 & \\
\hline on & X B) & 0.63 & & & & & & & & & & 16 & & 3.79 & .73 & \\
\hline Iviet & & 0.31 & 0.60 & 0.30 & 0.44 & 0.56 & 0.3 & 0.55 & 0.31 & 0.30 & 0.18 & 0.08 & 0.08 & 36.90 & 29.36 & 21.87 \\
\hline Treated vs u & untreated (D) & & & & ** & $\star *$ & 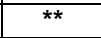 & $\neq \star$ & 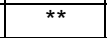 & & $*$ & $*$ & $t$ & & t5 & 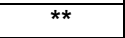 \\
\hline teraction & $(A \times D)$ & $\star \star \star$ & & * & ** & ** & & ** & $\star \star$ & & ** & $\star \star \star$ & 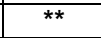 & & $\pi$ & \\
\hline
\end{tabular}

${ }^{*},{ }^{\star \star}$ and indicate significant at 0.05 and 0.01 , respectively.

One ardab $=155 \mathrm{~kg}$ 
Table 7. Interaction between two cultivars of faba bean and application methods with micronutrients in 2004/2005 and 2005/2006 seasons.

\begin{tabular}{|c|c|c|c|c|c|c|c|c|c|c|c|c|c|c|c|c|}
\hline \multirow{2}{*}{ Cultivar } & \multirow{2}{*}{$\begin{array}{l}\text { Application } \\
\text { method }\end{array}$} & \multicolumn{3}{|c|}{ No. of pods / plant } & \multicolumn{3}{|c|}{$\begin{array}{c}\text { Seed weight / plant } \\
\text { (g) }\end{array}$} & \multicolumn{3}{|c|}{$\begin{array}{c}\text { 100-seedweight } \\
\text { (g) }\end{array}$} & \multicolumn{3}{|c|}{$\begin{array}{l}\text { Seed yield / feddan } \\
\text { (ardab) }\end{array}$} & \multicolumn{3}{|c|}{$\begin{array}{c}\text { Straw yield / feddan } \\
(\mathrm{kg})\end{array}$} \\
\hline & & $\begin{array}{c}1^{1^{\text {st }}} \\
\text { season }\end{array}$ & $\begin{array}{c}2^{\text {nd }} \\
\text { season }\end{array}$ & Comb. & $\begin{array}{c}1^{\text {st }} \\
\text { season }\end{array}$ & $\begin{array}{c}2^{\text {nd }} \\
\text { season }\end{array}$ & Comb. & $\begin{array}{c}1^{\text {st }} \\
\text { season }\end{array}$ & $\begin{array}{c}2^{\text {nd }} \\
\text { season }\end{array}$ & Comb. & $\begin{array}{c}1^{\text {st }} \\
\text { seasor }\end{array}$ & $\begin{array}{c}2^{\text {nd }} \\
\text { season }\end{array}$ & Comb. & $\begin{array}{c}1^{\text {st }} \\
\text { seasor }\end{array}$ & $\begin{array}{c}2^{\text {nd }} \\
\text { season }\end{array}$ & Con \\
\hline \multirow{3}{*}{ Giza 40} & Coating & 29.30 & 30.95 & 30.13 & 45.34 & 44.54 & 44.94 & 62.64 & 61.03 & 61.84 & 12.47 & 12.45 & 12.46 & 1858.7 & 2090.3 & 1974.5 \\
\hline & Spray & 31.00 & 32.70 & 31.85 & 49.78 & 51.41 & 50.60 & 65.23 & \begin{tabular}{|l|}
63.47 \\
\end{tabular} & 64.35 & 13.42 & 13.60 & 13.51 & 1984.1 & 2202.9 & 2093.5 \\
\hline & Coating + Spray & 29.00 & 30.45 & 29.73 & 42.83 & 44.21 & 43.52 & 62.04 & 61.17 & \begin{tabular}{|l|}
61.61 \\
\end{tabular} & 12.05 & 12.31 & 12.18 & 1825.2 & 1990.6 & $\mid 1907.9$ \\
\hline \multirow{3}{*}{ Nubaria 1} & Coating & 18.90 & 20.60 & 19.75 & 69.99 & 79.90 & 74.95 & 115.87 & 118.63 & 117.25 & 17.92 & 18.71 & 18.32 & 2728.9 & 3026.6 & 2877.8 \\
\hline & Spray & 20.65 & 21.70 & 21.18 & 80.37 & 88.01 & \begin{tabular}{|l|}
84.19 \\
\end{tabular} & 120.08 & 122.80 & 121.44 & 19.29 & 20.25 & 19.77 & 2948.7 & 3295.9 & 3122.3 \\
\hline & Coating + Spray & 18.50 & 20.10 & 19.30 & 67.52 & 77.2 & \begin{tabular}{|l|}
72.36 \\
\end{tabular} & 114.43 & 118.48 & 116.46 & 17.38 & 18.55 & 17.97 & 2678.5 & 2919.4 & \begin{tabular}{|l|}
2798.9 \\
\end{tabular} \\
\hline \multicolumn{17}{|c|}{ L.S.D. (0.05) For: } \\
\hline $\begin{array}{r}\operatorname{lnt} \\
\text { ultivar } \mathbf{x} \mathrm{n}\end{array}$ & $\begin{array}{l}\text { action } \\
\text { thod }\end{array}$ & NS & NS & NS & 0.63 & 0.80 & 0.51 & 0.78 & 0.44 & 0.46 & 0.26 & 0.11 & 0.13 & 52.18 & 41.53 & 33.46 \\
\hline
\end{tabular}

NS indicate insignificant at 0.05 and 0.01 , respectively.

One ardab $=155 \mathrm{~kg}$ 